\title{
POPULATION POTENTIAL AS A MODULATOR OF LAND USE CHANGES IN POLAND'S METROPOLITAN AREAS*
}

\author{
Piotr Werner ${ }^{1}$, Piotr Korcelli ${ }^{2}$, Elżbieta KozUbeK ${ }^{3}$ \\ ${ }^{1}$ Faculty of Geography and Regional Studies, University of Warsaw, Poland \\ ${ }^{2}$ Stanisław Leszczycki Institute of Geography and Spatial Organization, Polish Academy of Sciences, Warsaw, \\ Poland \\ ${ }^{3}$ Mazovian Office for Regional Planning, Warsaw, Poland
}

Manuscript received: February 14, 2014

Revised version: March 17, 2014

Werner P., Korcelli P., Kozubek E., 2014. Population potential as a modulator of land use changes in Poland's metropolitan areas. Quaestiones Geographicae 33(2), Bogucki Wydawnictwo Naukowe, Poznań, pp. 37-50, 3 tables, 8 figs. DOI 10.2478/quageo-2014-0014, ISSN 0137-477X.

Aвstract: Land use is defined as a spatial distribution of individual forms of land cover patches, utilised or not utilised by humans within the framework of mutual and spatial relationships. It refers to the functional character of a given terrain, and is also identified with a socio-economic description of the land surface. Changes in land use can be interpreted as a complex and, to some extent, a random process. These assumptions serve as a point of departure in an attempt to evaluate spatial and temporal differences in land use changes in the metropolitan areas of Poland, using the entropy formula. The analysis focuses on population development as a factor that impacts upon land use change. The approach proposed here allows us to study land use dynamics in detail, with the help of cartographic visualisation.

KEY WORDS: land use, metropolitan area, population potential, entropy

Piotr Werner, Faculty of Geography and Regional Studies, University of Warsaw, Krakowskie Przedmieście 30, 00-927 Warsaw, Poland; e-mail: peter@uw.edu.pl

Piotr Korcelli, Stanisław Leszczycki Institute of Geography and Spatial Organization, Polish Academy of Sciences, Twarda 51/55, 00-818 Warsaw, Poland; e-mail:korcelli@twarda.pan.pl

Elżbieta Kozubek, Mazovian Office for Regional Planning, Solec 22, 00-410 Warsaw, Poland; e-mail: ekozubek@mbpr.pl

* Partial results of the research project "Spatial interactions and external effects of land use changes in metropolitan areas in Poland", granted by the Polish National Science Centre (UMO-2011/01/B/HS4/05194), carried out at the Institute of Geography and Spatial Organization, Polish Academy of Sciences.

\section{Introduction}

This study concerns interrelations between population development and land use change within metropolitan areas of Poland. Over the last decades Poland's urban agglomerations have experienced a far-going functional and spatial transformation, including the suburbanisation and peri-urbanisation trends - general characteristics of metropolitanisation processes (Korcelli 2005, Parysek 2005, OECD 2011).

The selection of study areas (12 in total) for the purpose of the analysis is mainly based on Poland's Spatial Development Concept till 2030 (KPZK 2011). In this policy document elaborated at the Ministry of Regional Development, the following 
cities are identified as metropolitan centres: Warsaw, Katowice (main centre of the Upper Silesian conurbation), Cracow, Łódź, Gdańsk-Gdynia, Wrocław, Poznań, Bydgoszcz-Toruń, Szczecin, and Lublin. The two additional areas chosen focus on Białystok and Rzeszów - lower-ranking regional centres frequently referred to in the planning literature as 'potential', i.e. prospective metropolitan cities. With regard to the spatial extent of metropolitan areas, the delineation used is that applied in the Urban Audit project (Eurostat data), based primarily on commuting to work. The outer boundaries of the metropolitan areas were kept constant for the whole period of analysis, i.e. 1990-2006. Within this time span two sub-periods were distinguished: 1990-2000 and 2000-2006. These time limits are determined by the availability of land use data as provided in the Corine Land Cover inventories. The original data files were transformed and aggregated into 16 land use categories ${ }^{1}$.

Relations between economic and demographic processes and urban land use are complex and of a two-sided character (Bourne 1978). They can only partly be interpreted by resorting to the neoclassical theory of urban land rent (Alonso 1964; see also McCann and Sheppard 2003). Among the particularly intricate aspects is the timing of land use change - the length of time lags in response to specific external factors. Johansson (1986), following the classification proposed by Snickars (1985), identifies the impacts of locational dynamics of economic and demographic processes upon land use with an intermediate level of the time scale. Long-term, slow adjustments of land use patterns correspond to the development of fixed urban capital built on land. Conversely, short-term adjustments refer to variations in land use characteristics attributed to the interaction between economic and social activities within a given regional setting (see also Batty 2008).

These are the following: continuous urban fabric, discontinuous urban fabric, industrial or commercial units, transport areas, airports, mineral extraction and dump sites, construction sites, green urban areas, sport and leisure facilities, agricultural areas, pastures, forests, natural and semi-natural vegetation, inland marshes and peat bogs, water courses and bodies, sea and ocean.
It is the latter type of interdependence that provides the conceptual framework for the present study. Owing to a wide range of specialised functions, as well as the role performed in the spatial organisation of economic activity and settlement systems at both national and international levels, metropolitan areas constitute fields of intense interaction expressed in mutually interwoven flows of people, goods and information. Such location-specific flows are linked, in the form of a cause-and-effect chain, with evolving patterns of land use. This relationship is traced here over time. While values of the population potential at given locations (individual spatial units) serve as a proxy for the volume of spatial interactions, trends in land use change are expressed in terms of its concentration and dispersion among individual land use categories, and are measured by the entropy function. It is hypothesised that depending on the direction of change, the changing population potential values are accompanied by the transition of land use patterns that leads either to their increased diversity, reflected in higher values of the entropy indicator, or to greater homogeneity, as observed at the level of individual municipalities.

\section{Population potential quotients as correlates of land use changes}

Spatial interactions represent flows of activity between locations in geographical space (Batty 2008). These may be flows of people, represented by population potential values. Population potential is a measure of nearness, or accessibility, of a certain aggregation of people to a given point. The term is derived from social physics, and the concept is closely connected to that of the gravity model, in that it relates mass (population) to distance (Stewart 1948; Warntz 1957). Whereas the gravity model deals with separate relationships between pairs of points, population potential encompasses the influence of all other points on a particular one (Johnston 1985).

Population potential is sometimes defined as the possibility of interactions, i.e. the total ability of places (regions) to generate spatial interactions. In this sense, the value of the potential at a given point is a sensitive indicator of changes, 
including land use changes that occur in geographical space, particularly in urbanised areas. It should be noted that a similar interpretation may pertain to changing population density values (Bourne 1978).

Population potential has been used in urban and regional studies in Poland (Chojnicki 1999), in the modelling of commuting, transport networks (Ratajczak 1999), and simulations of ICT networks (Werner 2003). In terms of the economic development level and land use changes, population potential values were interpreted, inter alia, by Kozubek (in Korcelli et al. 2012) and Czyż (1995).

In this study population potential is treated as an appropriate measure of accessibility, and a tool for an assessment of the volume of interaction involving alternative locations. The general potential model assumes that interactions pertaining to a given location decline proportionally to the distance from the origin. The larger the population potential in the target location, the greater its ability to generate spatial interactions. The population potential model encompasses both the population size of places (nominator) and the distance (denominator) involved; the latter expresses the friction of space. The nominator represents the total number of people able to overcome the resistance of geographical space, or the number of potential trips.

The model applied here includes a term corresponding to Zipf's rule of rank and the population size of spatial units (Werner 2003), namely:

$$
V_{i}=\sum_{\substack{j=1 \\ i \neq j}}^{n}\left(\frac{P_{j}}{d_{j}}\right) h_{j}^{-1}
$$

where:

$V_{i}$ - the population potential of $i^{\text {th }}$ municipality

$P_{j}$ - the population of $j^{\text {th }}$ municipality

$d_{i j}$ - the geographical distance in $\mathrm{km}$ between the municipalities $i$ and $j$

$h_{i j}$ - the difference in hierarchy between the municipalities $i$ and $j$.

Values of population potential at the level of individual municipalities, as of 1990, 2000 and 2006, were calculated for Poland as a whole, but only those municipalities that fall within the boundaries of metropolitan areas were considered in the analysis.
In the next step, quotients of population potential were examined for the defined subset of metropolitan municipalities: [2000/1990] and [2006/2000]. This procedure made it possible to assess changes in the intensity of spatial interactions. The quotients of population potential (indices of dynamics of spatial interactions) fall in the range $(0 ; \infty)$. For value equal to one, there is no change (stability); values less than one mean a decline in spatial interactions; and values greater than 1 are interpreted as a growing intensity of spatial interactions.

\section{Entropy as a measure of land use diversification}

Entropy is a universal measure of dispersion. The entropy index is not vulnerable to its operationalisation. It is used in the analysis of various systems (including socio-economic ones) to obtain measures of concentration and divergence of random variables (Wilson 1970, 2000; Wędrowska 2012). The Shannon formula of entropy was applied for the purpose of this study, and the input data were the shares of individual land use types (classes). As mentioned earlier, the structure of land use of the metropolitan areas in Poland was generalised into 16 classes. Then, the set of entropy indices was calculated - for each municipality separately for 1990, 2000 and 2006, using the following formula:

$$
E=-\sum_{i=1}^{n} p_{i} \log _{2}\left(p_{i}\right)
$$

where:

$p_{i}-$ probability of given land use class in municipality (share of land use class in $\%$ of total area of municipality)

$i$ - given land use class (nominal order)

$n$ - total number of land use classes in study $(n=16)$

$E$ - value of entropy index of land use.

The growth of entropy over time can be interpreted as a measure of increase in the spatial differentiation of land use (a greater number of land use classes) in a given municipality. Conversely - a decline in entropy implies increasing land use homogeneity in the study area. 
Entropy is a continuous function with non-negative values, independent of the position of the component elements. The entropy index takes values in the range of $\left[0, \log _{2} n\right]$, with the minimum, or zero, for the whole area featuring only one type (class) of land use, and the maximum (equal 4 in the study) for equal patches of area in all possible land use classes.

Following the calculation of entropy indices, their quotients were estimated for the same time intervals as in the case of population potential. This procedure made it possible to evaluate land use dynamics. Quotients of entropy equal to one mean that no change took place in the shares of individual land categories. Values greater than one show an entropy increase and differentiation of land use (growth of disorder). Values of entropy change less than one describe a tendency towards the unification of land use, i.e. a greater order of structure, and growing dominance of a particular land use class.

\section{Analytical framework}

According to the working hypothesis as formulated in the introductory section, along with the changing intensity of human interaction in space (which is here expressed by values of the population potential index), the observed patterns of land use evolve to become more diversified or more uniform over space. At the same time, there is a positive correlation between rates of change of the indicators used. The verification of the hypothesis relied on confrontation of the quotients of population potential $(\delta V)$ and entropy $(\delta E)$ for the corresponding time periods. There are four (theoretical) possibilities of the pattern of change (see Table 1):

$\delta V>1$ and $\delta E>1$ : growing potential for spatial interaction is accompanied by increasing differentiation of land use patterns. This type of change is normally associated with progressing peri-urbanisation, and can be defined as metropolitan expansion.

$\delta V \leq 1$ and $\delta E>1$ : a decreasing volume of potential interaction in space corresponds with the transition of land use that leads to its differentiation. This can occur as an effect of dispersion of settlement in certain zones, with accompanying development of green and blue infrastructure, and can be linked with the urban conservation perspective (Ravetz et al. 2013).

$\delta \mathrm{V}>1$ and $\delta \mathrm{E} \leq 1$ : increasing population potential values are positively correlated with decreasing differentiation of land use patterns, as recorded at the level of individual municipalities. This type of relationship can be related to the urbanisation containment perspective.

$\delta \mathrm{V}<1$ and $\delta \mathrm{E}<1$ : decreasing potential for spatial interaction is associated with growing homogeneity of land use. This suggests the phenomenon of urbanisation shrinkage, although it can also imply a land use consolidation process, following an earlier phase of urban expansion.

A special case of the relationship - a theoretically valid one - is the situation in which the two relevant quotient values are equal to one, i.e. practically no change in the population potential and the land use dispersion indicator is registered.

On the basis of the contingency table presented below, the relevant sets of observations pertaining to individual municipalities are subjected to Chi-square statistical tests. The zero hypothesis assumes independence of the magnitude (rate) of change of the two indicators, i.e. population potential and land use entropy.

\section{Spatial interactions in the metropolitan areas}

Spatial and temporal variations in the values of population potential by individual municipalities are presented in Figures 1, 2 and 3. There were minimal changes in the values of population potential during the 1990-2000 decade (the dispersion along the line of no change in Fig. 3). As the maps indicate, the biggest changes were observed in peripheral areas (both of growth and decline of population potential). There were fluctuations in the index of spatial interactions. The growth of spatial interactions can be interpreted as mounting population pressure, while a decline in spatial interactions implies decreasing population pressure. 
Table 1. Comparison of theoretical values of spatial-temporal quotients of entropy of land use and quotients of spatial interactions (population potentials, see explanation in text)

\begin{tabular}{|c|c|c|c|}
\hline \multirow{2}{*}{\multicolumn{2}{|c|}{ Land use }} & \multicolumn{2}{|c|}{$\begin{array}{c}\delta \mathrm{V} \\
\text { quotient of population potential (intensity of spatial interactions) }\end{array}$} \\
\hline & & $\begin{array}{c}>1 \\
\text { human impact }\end{array}$ & $\begin{array}{c}<1 \\
\text { decline of population pressure }\end{array}$ \\
\hline \multirow[b]{2}{*}{$\begin{array}{l}\text { quotient of entropy (dy- } \\
\text { namics of land use change) }\end{array}$} & $\stackrel{>1}{\text { differentiation }}$ & $\begin{array}{c}\text { A } \\
\text { metropolitan } \\
\text { expansion }\end{array}$ & $\begin{array}{c}\text { B } \\
\text { urban } \\
\text { conservation }\end{array}$ \\
\hline & $\begin{array}{l}<1 \\
\text { unification }\end{array}$ & $\begin{array}{c}\text { C } \\
\text { urbanisation } \\
\text { containment }\end{array}$ & $\begin{array}{c}\mathrm{D} \\
\text { land use } \\
\text { consolidation }\end{array}$ \\
\hline
\end{tabular}

Table 2. Types of relations between quotients of population potential and quotients of entropy indices by number of municipalities (2000/1990, see explanation in text)

\begin{tabular}{|c|c|c|c|}
\hline $\begin{array}{r}\text { Spatial interac- } \\
\text { tions }\end{array}$ & $\begin{array}{r}\delta \mathrm{V}>1 \text { human impact } \\
\text { Land use }\end{array}$ & $\begin{array}{c}\delta \mathrm{V}<1 \text { decline of population } \\
\text { pressure }\end{array}$ & Total no. of municipalities \\
\hline$\delta \mathrm{E}>1$ differentiation & $\begin{array}{c}614 \\
\text { A } \\
\text { metropolitan expansion }\end{array}$ & $\begin{array}{c}464 \\
\text { B } \\
\text { urban conservation }\end{array}$ & 1,078 \\
\hline $\begin{array}{c}24 \\
\text { C }<1 \text { unification }\end{array}$ & $\begin{array}{c}42 \\
\text { D } \\
\text { urbanisation containment }\end{array}$ & land use consolidation & 66 \\
\hline $\begin{array}{c}\text { Total no. of municipal- } \\
\text { ities }\end{array}$ & 638 & 506 & 1,144 \\
\hline
\end{tabular}

Table 3. Types of relations between quotients of population potential and quotients of entropy indices by number of municipalities (2006/2000, see explanation in text)

\begin{tabular}{|c|c|c|c|}
\hline $\begin{array}{r}\text { Spatial } \\
\text { interactions }\end{array}$ & $\begin{array}{c}\delta \mathrm{V}>1 \\
\text { Luman impact }\end{array}$ & $\begin{array}{r}\delta \mathrm{V}<1 \\
\text { decline of population } \\
\text { pressure }\end{array}$ & Total no. of municipalities \\
\hline \multirow{2}{*}{$\delta \mathrm{E}>1$ differentiation } & $\begin{array}{c}239 \\
\mathrm{~A}\end{array}$ & $\begin{array}{c}233 \\
\mathrm{~B}\end{array}$ & 478 \\
\hline \multirow{2}{*}{$\delta \mathrm{E}<1$ unification } & $\begin{array}{c}\text { metropolitan expansion } \\
\text { urban conservation }\end{array}$ & $\begin{array}{c}365 \\
\mathrm{D}\end{array}$ & 666 \\
\hline Total no. of municipalities & urbanisation containment & land use consolidation & \\
\hline
\end{tabular}

\section{Entropy of land use changes in the metropolitan areas}

During 1990-2000 a weak trend towards the differentiation of land use was observed in the metropolitan areas of Poland. The changes took place in relatively few, peripheral municipalities. Some symptoms of human impact were visible in Upper Silesia. The only exception was the Wrocław metropolitan area, characterised by an enormous decline in the entropy quotient. This could be interpreted as a consequence of the so- called Flood of the Century, which inflicted Lower Silesia, including the city of Wrocław, in 1997.

An opposite situation is presented on the map for 2000-2006. There is a growing differentiation of land use in the case of Wrocław, Poznan and Łódź metropolitan areas - both in the central and some peripheral municipalities. In other areas the process of a decline in entropy quotients, i.e. the uniformisation of land use, is noted.

In the last decade of the 20th century two parallel tendencies can be observed, with the predominance of differentiation over unification of land use. In the early years of the 21st century op- 


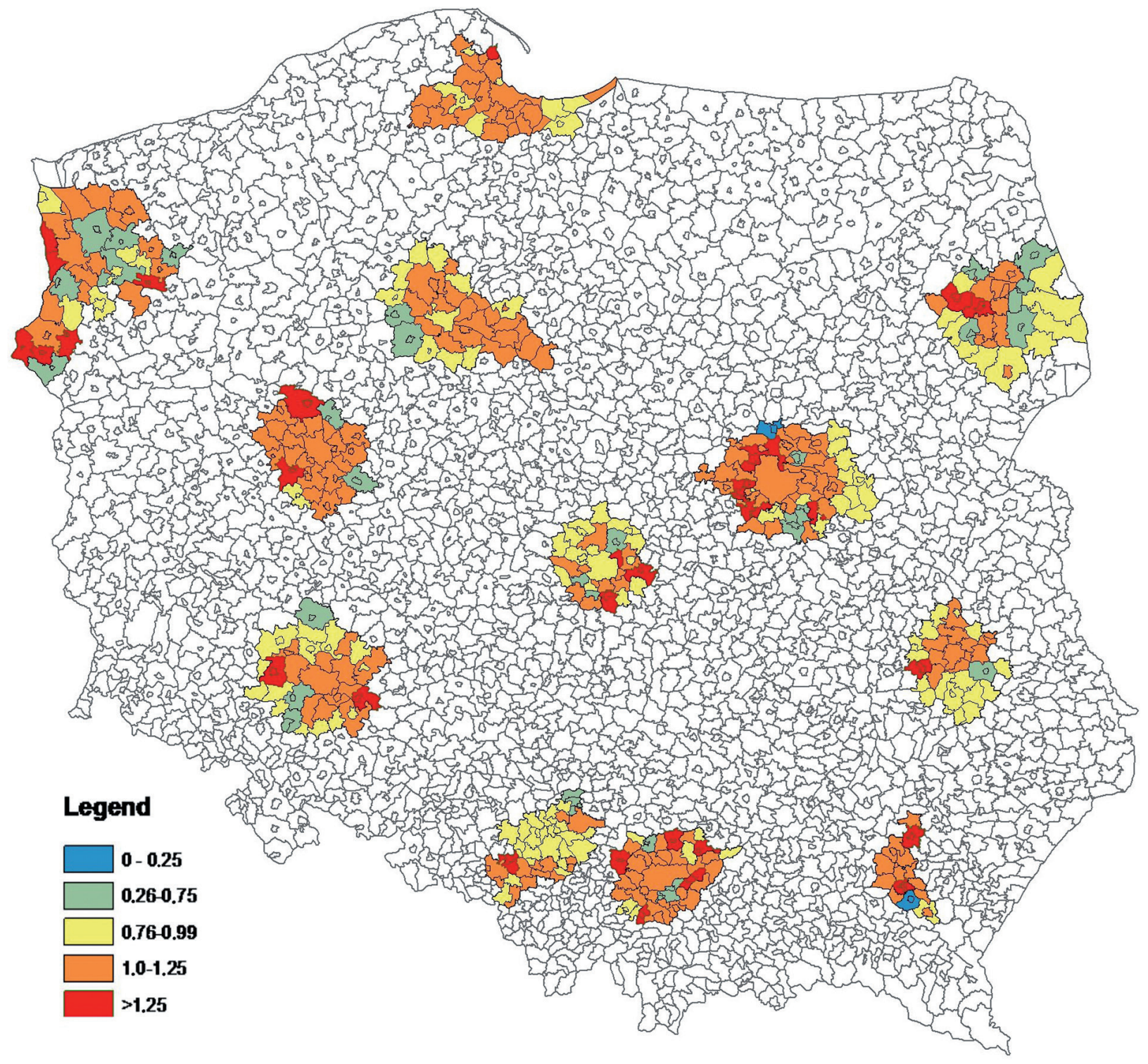

Fig. 1. Dynamics of spatial interactions in municipalities of the metropolitan areas of Poland (2000/1990, see explanation in text)

posite processes take place simultaneously within all the metropolitan areas: some municipalities display the differentiation of land use, others its growing uniformisation. However, these processes seem to occur rather slowly.

\section{Statistical analysis of population potential - land use interdependence}

The following could be observed in 19902000: a general tendency towards differentiation of land use changes, in spite of diverging directions of change in population pressure. This can be interpreted as the result of two general processes of human impact in urbanised areas and re-naturalisation of relatively depopulated areas.

The Chi-square test with the value of $\chi^{2}=4.22$ proves that the hypothesis of independence for the contingency table should be rejected, with the significance level equal to $p=0.05$. The spatial pattern of relevant values is presented in Fig. 7 .

Similar processes took place during the next time interval (2000-2006), although a different spatial distribution was observed. The Chi-square test with the value of $\chi^{2}=2.578$ proves that the hypothesis of independence for the contingency table should not be rejected, with the significance 


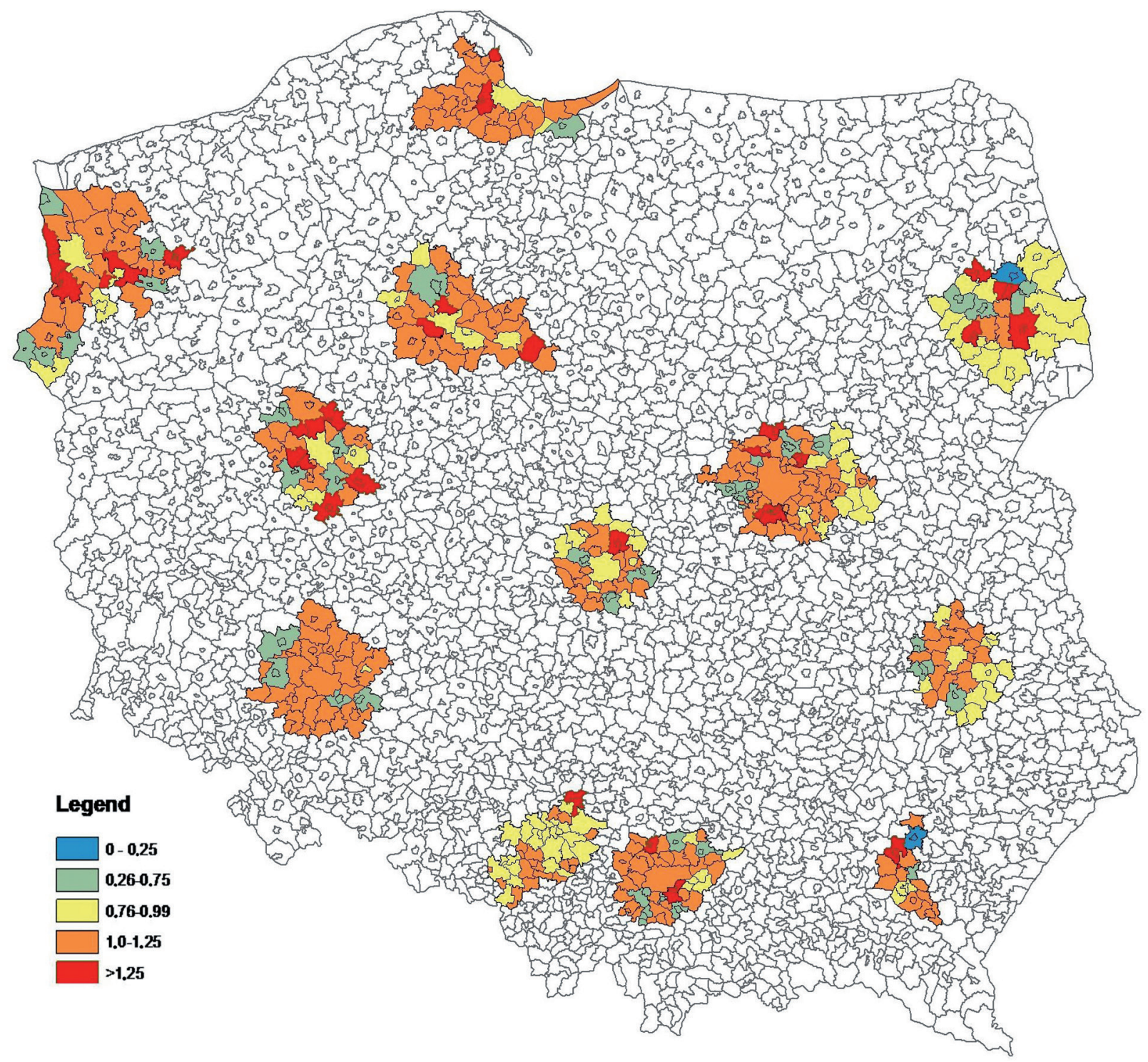

Fig. 2. Dynamics of spatial interactions in municipalities of the metropolitan areas of Poland (2006/2000, see explanation in text)

level equal to $p=0.108$. The spatial pattern of the relationship is presented in Fig. 8.

As indicated above, the first time interval (1990-2000) was characterised by the prevalence of processes of land use differentiation within the municipalities under study. The dominant trends observed were those of metropolitan expansion and urban conservation. Spatial clusters forming compact zones of expansion or conservation, specific to each metropolitan area, can clearly be distinguished. During that decade human impact in the inner zones characterised the following metropolitan areas: Warsaw (WMA), Cracow (CMA), Poznań (PMA), Lublin (LMA), and Białystok (BMA). In the remaining MAs spa- tial interactions were growing in the suburban areas. The only exception was Wrocław, with the predominant tendencies towards urbanisation containment and land use consolidation, respectively. These patterns again formed quite compact zones.

The second time interval studied (2000-2006) was characterised by the prevalence of uniformisation of the land use structure at the municipality level. All the processes defined could be observed, with municipalities characterised by similar types of change forming spatial clusters - compact zones within the boundaries of each metropolitan area under study. 


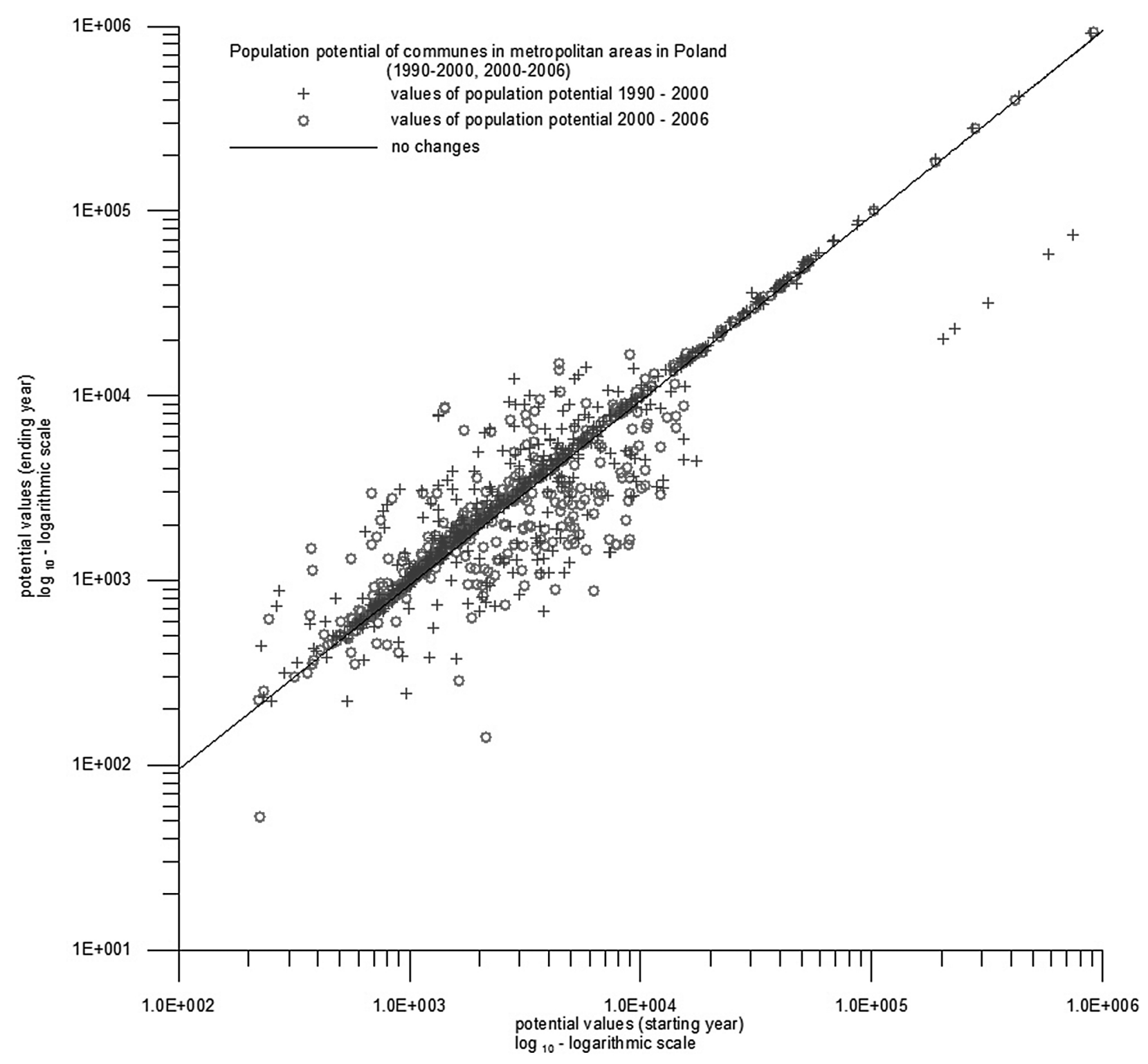

Fig. 3. Population potential by municipalities of the metropolitan areas in Poland (1990-2000-2006)

The following groups of MAs featuring similar patterns of change can be identified: (1) WrMA, PMA, ŁMA, with urban conservation in the inner zones and urbanisation (metropolitan expansion) in the suburban areas, and (2) WMA, BMA and RMA, with urbanisation containment in the core and, again, metropolitan expansion in the suburban areas. The remaining MAs differ in their spatial development patterns; however, their inner zones are mostly characterised by the urban consolidation process. 


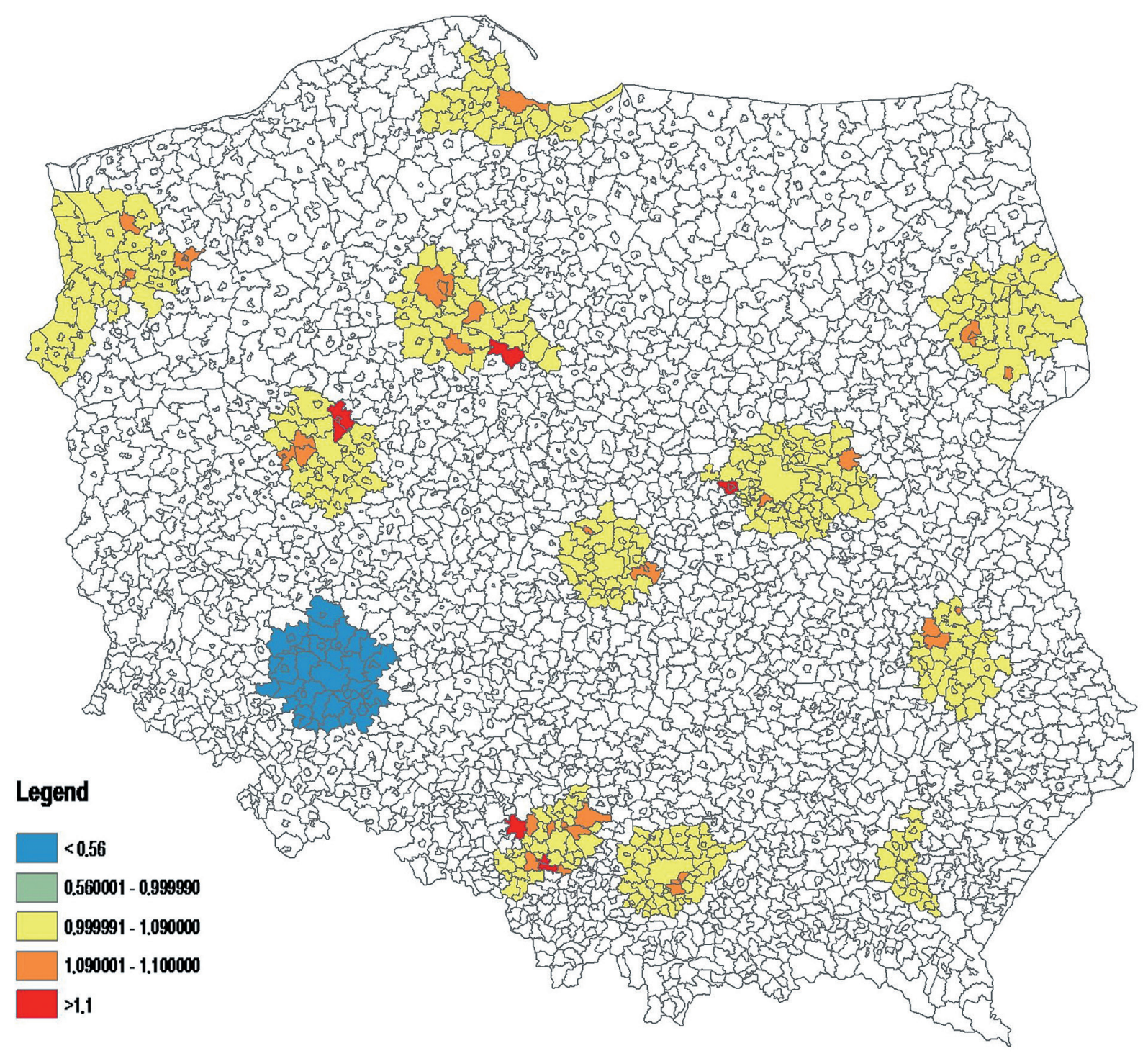

Fig. 4. Dynamics of entropy of the land use structure in municipalities of the metropolitan areas of Poland (2000/1990, see explanation in text) 


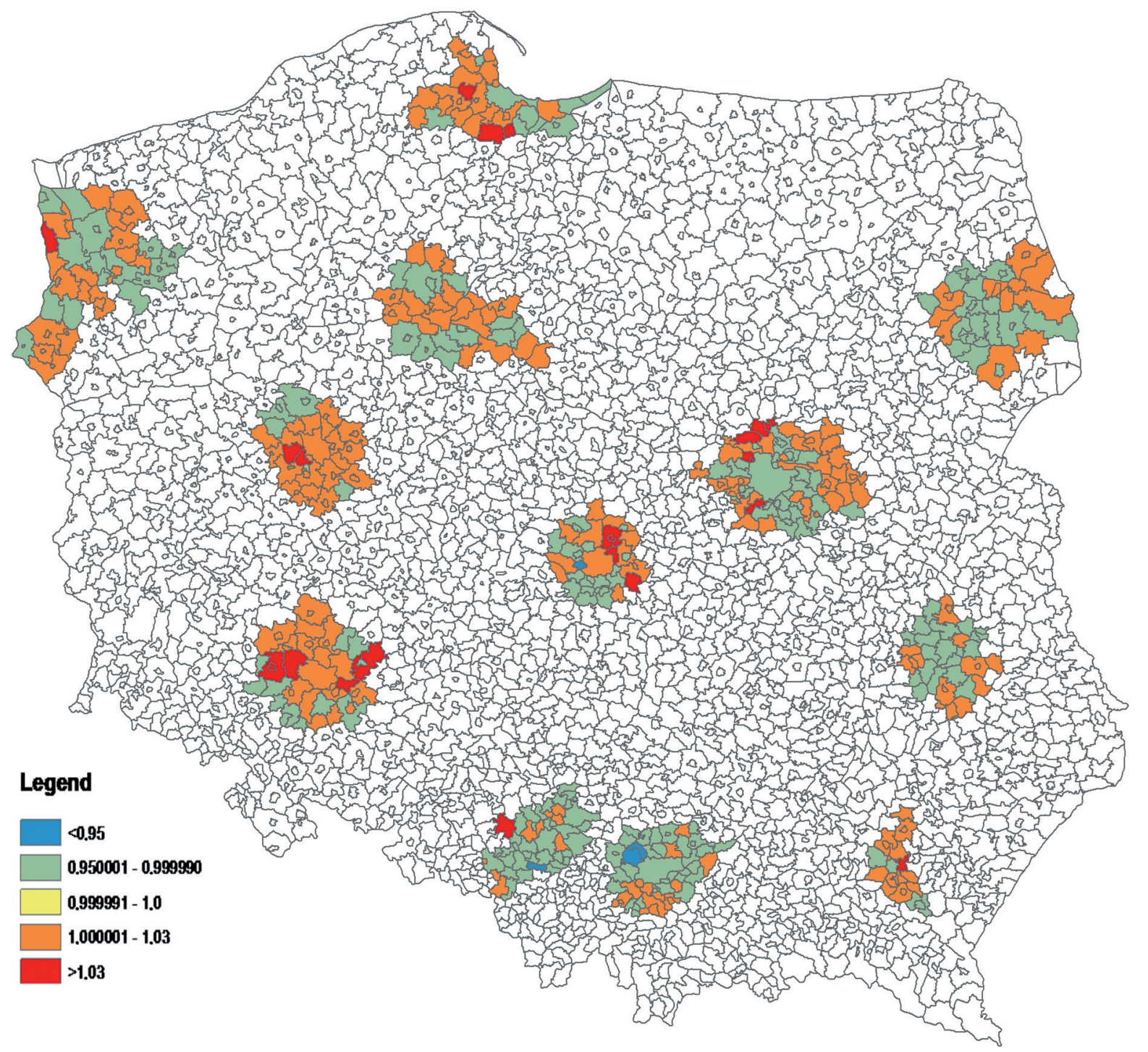

Fig. 5. Dynamics of entropy of the land use structure in municipalities of the metropolitan areas of Poland (2006/2000, see explanation in text) 


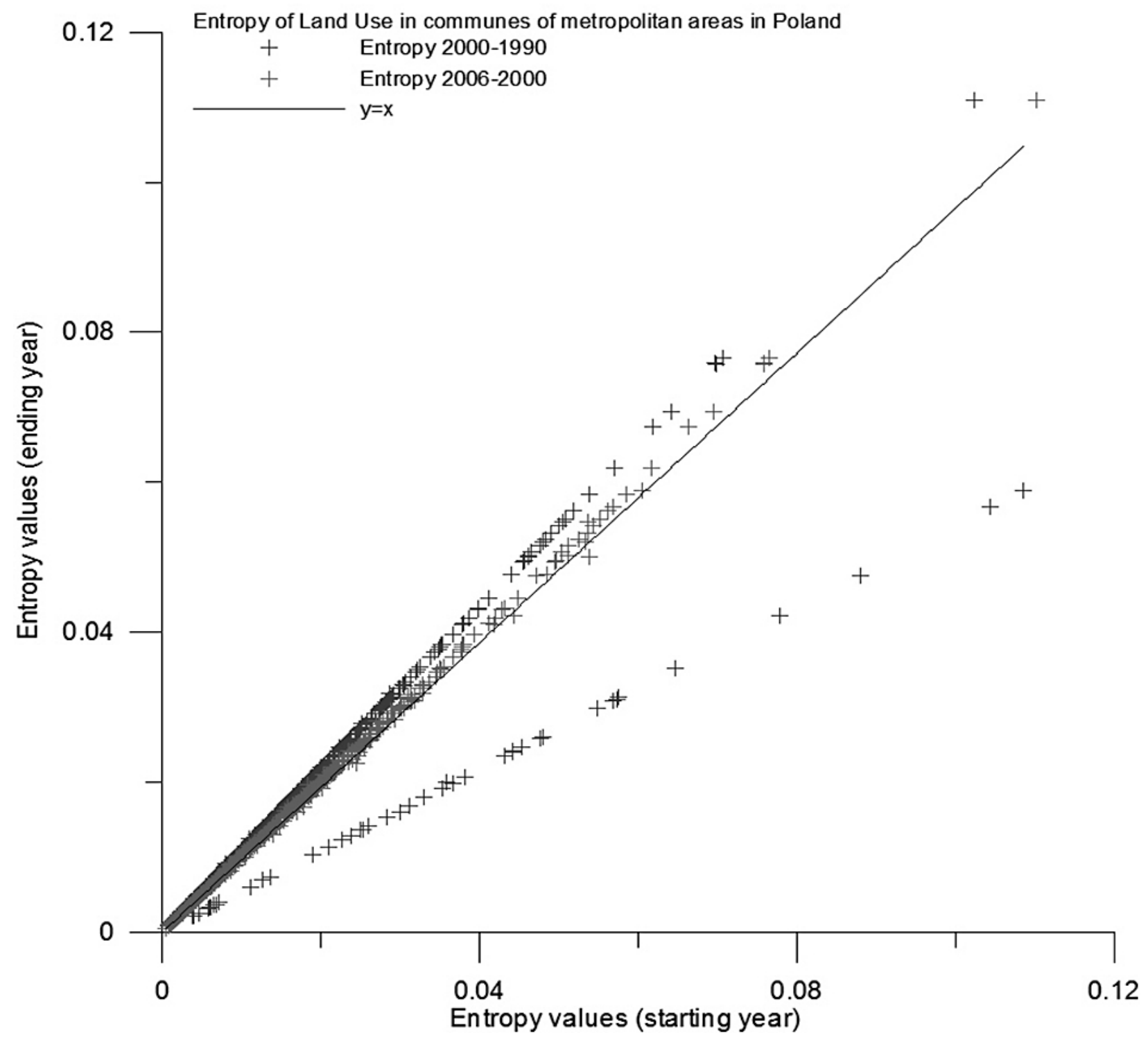

Fig. 6. Entropy of land use in municipalities of the metropolitan areas in Poland (1990-2000-2006) 


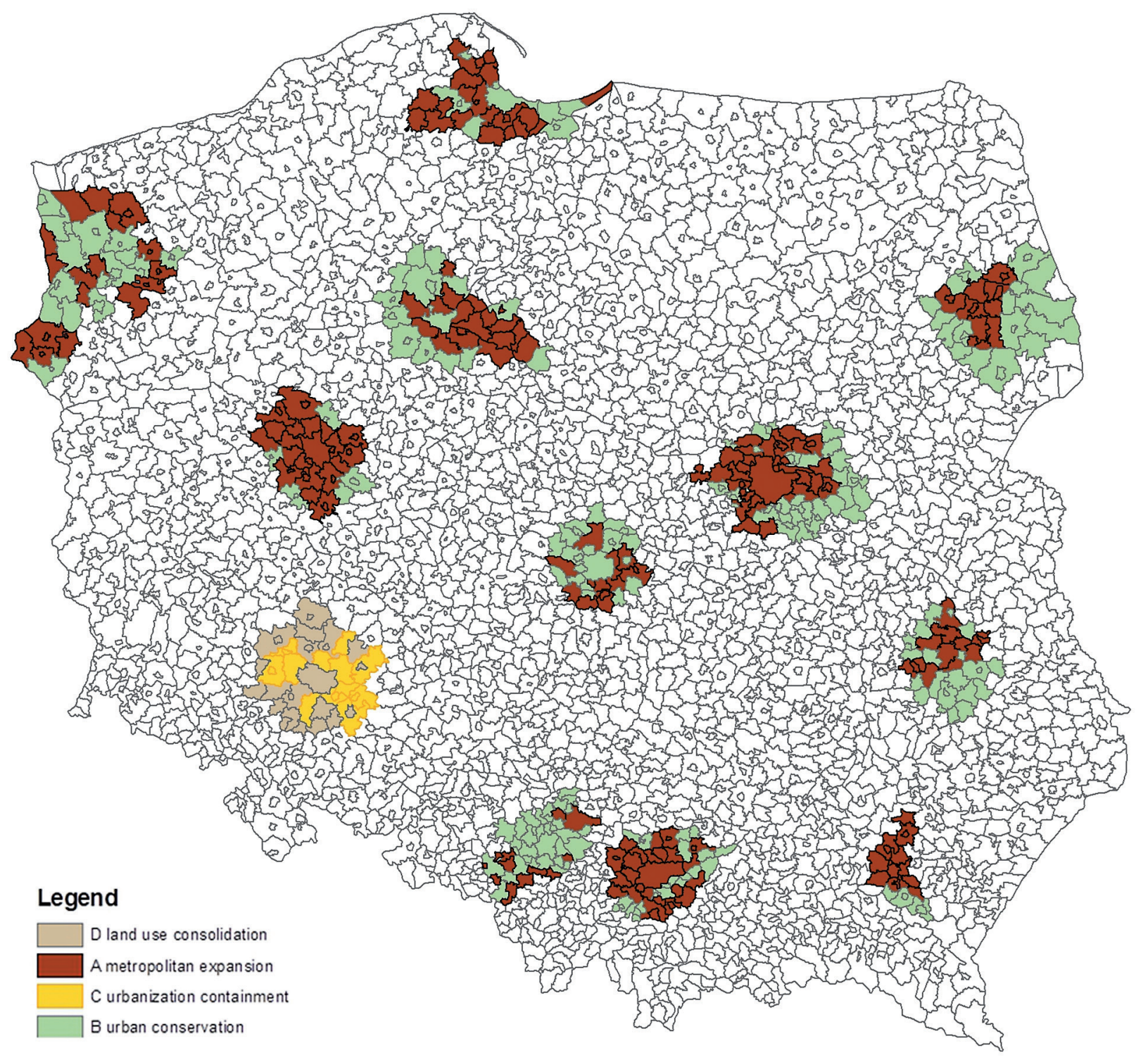

Fig. 7. Spatial interactions vs. land use changes in the metropolitan areas of Poland (quotients of population potentials vs. quotients of entropy values), 2000/1990 


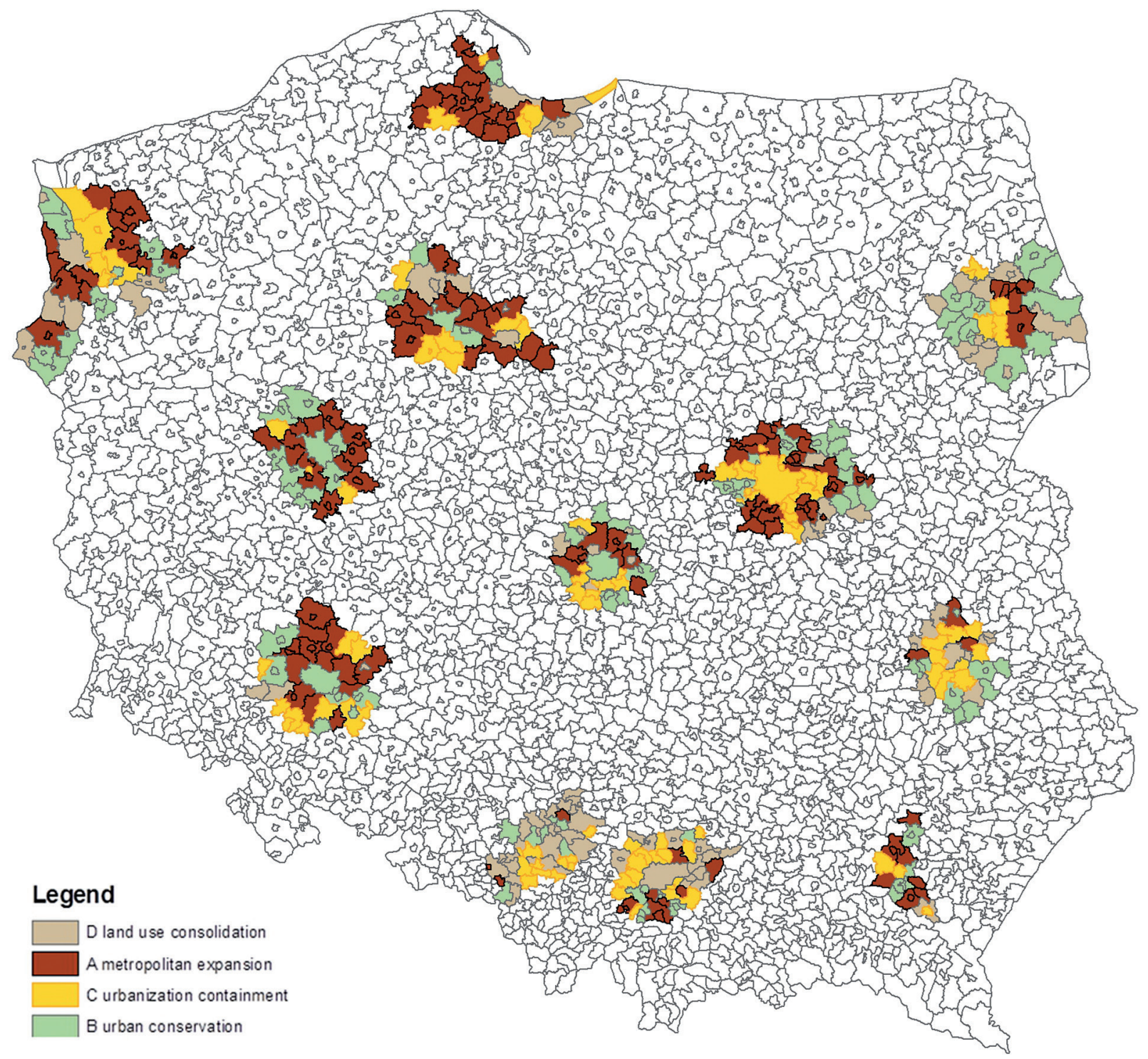

Fig. 8. Spatial interactions vs. land use changes in the metropolitan areas of Poland (quotients of population potentials vs. quotients of entropy indices), 2006/2000. 


\section{Conclusions}

The period covered in the present study can be depicted as an early phase of metropolitanisation processes, which in Poland corresponds to, and follows, the systemic transformation of the 1990s. During this time suburbanisation and peri-urbanisation largely assumed the character of urban sprawl, with a limited role of spatial planning and a prevailing competitive rather than cooperative approach to development taken by individual municipalities in their effort to attract infrastructural, commercial and residential investments.

Under such conditions one may anticipate some instability in the observed patterns of urban change. This is confirmed by the results of the study. The corroboration of the hypothesis of a bilateral positive relation between increasing population pressure and growing differentiation of land use change in the first time interval, and its rejection in the case of the second interval, suggests that different external factors were involved which influenced the observed processes.

The results obtained allow us to formulate new questions concerning some externalities that operated within the individual metropolitan areas. Their identification is in fact the ultimate target of the research project the preliminary part of which is presented here. The research scheme seems to have proved its value so far, and should be applied at a broader scale in order to identify spaces in which such external factors are at work.

\section{References}

Alonso W., 1964. Location and land use: Toward a general theory of land rent. Harvard University Press, Cambridge, Mass.

Batty M., 2008. Spatial interaction. In: Kemp K.K. (ed.), Encyclopedia of Geographic Information Science. Sage, Thousand Oaks, CA: 416-418 (Sage Reference Online, accessed 10 Jan. 2012).

Bourne L.S., 1978. On the complexity of urban land use change: Or, what theoretical models leave in the dust. Papers in Regional Science 41(1): 75-100.

Chojnicki Z., 1999. Podstawy metodologiczne i teoretyczne geografii (Methodological and theoretical foundations of geography). Bogucki Wydawnictwo Naukowe, Poznań.
Czyż T., 1995. Application of the population potential model in the structural regionalisation of Poland. Geographia Polonica 66(1): 13-31.

Johansson B., 1986. Introduction. Spatial dynamics and metropolitan change. Regional Science and Urban Economics 16(1): $1-6$.

Johnston R.J., 1985. The dictionary of human geography. Wiley-Blackwell, Oxford.

Korcelli P., 2005. The urban system of Poland. Built Environment (1978): 133-142.

Korcelli P., Grochowski M., Kozubek E., Korcelli-Olejniczak E., Werner P., 2012. Development of urban-rural regions: from European to local perspective. Monografie 14. IGiPZ PAN. Warszawa: 51-57.

Kozubek E.B., 2002. Zmiany użytkowania ziemi w regionie tarnobrzeskim pod wptywem uprzemystowienia w latach 19371992 w świetle interpretacji map i obrazów satelitarnych (Industrialisation-related changes in the land-use pattern in the Tarnobrzeg region over the years 1937-1992 in the light of the interpretation of maps and satellite images). Dokumentacja geograficzna, 25. IGiPZ PAN, Warszawa.

KPZK, 2011. Koncepcja Przestrzennego Zagospodarowania Kraju 2030 (Spatial Development Concept till 2030). Ministerstwo Rozwoju Regionalnego, Warszawa.

McCann P., Sheppard S., 2003. The rise, fall and rise again of industrial location theory. Regional Studies 37(6-7): 649-663.

OECD Library, 2011. Organisation for Economic Co-operation and Development. OECD Urban Policy Reviews. Paris.

Parysek J., 2005. Miasta polskie na przełomie XX i XXI wieku: rozwój i przekształcenia strukturalne (Polish cities in the late 20th and early 21st centuries: Development and structural changes). Bogucki Wydawnictwo Naukowe, Poznań.

Ratajczak W. 1999. Modelowanie sieci transportowych (Modelling of transport networks). Wydawnictwo Naukowe UAM, Poznań.

Ravetz J., Fertner C., Nielsen T., 2013. The dynamics of peri-urbanisation. In: Nilsson W.K., Pauleit S., Bell S., Aalbers C., Sick Nielsen T.A. (eds), Peri-urban futures: Scenarios and models for land use change in Europe. Springer, Berlin-Heidelberg: 13-44.

Snickars F., 1985. Beyond comparative analyses of metropolitan dynamics. Scandinavian Housing and Planning Research 2(3-4): 245-251.

Stewart J.Q., 1948. Empirical mathematical rules concerning the distribution and equilibrium of population. Geographical Review 37: 461-486.

Warntz W., 1957. Geography of prices and spatial interaction. Papers in Regional Science 3(1): 118-129.

Werner P., 2003. Geograficzne uwarunkowania rozwoju infrastruktury społeczeństwa informacyjnego w Polsce (Geographical determinants of the development of information society in Poland). Uniwersytet Warszawski, Wydz. Geografii i Studiów Regionalnych, Warszawa.

Wędrowska E., 2012. Miary entropii $i$ dywergencji w analizie struktur (Measures of entropy and divergence in an analysis of structures). Wydawnictwo UWM, Olsztyn.

Wilson A.G., 1970. Entropy in urban and regional modelling. Pion, London.

Wilson A.G., 2000. Complex spatial systems: The modelling foundations of urban and regional analysis. Pearson Education, New York. 